\title{
Improvement of soil properties and plant responses by compost generated from biomass of phytoremediation plant
}

\author{
Uhram Song ${ }^{\dagger}$ \\ Department of Biology and Research Institute for Basic Sciences, Jeju National University, Jeju 690-756, Republic of Korea
}

\begin{abstract}
Phytoremediation is an emerging green technology that uses plants to remediate environments contaminated with toxic materials. However, plants used for phytoremediation in the leachate channel of a sanitary landfill must be harvested and recycled to prevent re-release of contaminants during decomposition. Therefore, experiments were conducted to test the use of the harvested remediation macrophytes, Phragmites australis and Typha angustifolia, as composting material. Compost produced from these macrophytes significantly improved soil conditions, and, for plants grown in soil with macrophyte compost, their performance improved based on chlorophyll contents, a stress evaluation, and increase in biomass. Additionally, the bioaccumulation of contaminants was not high, with the concentrations of some elements even lower than those in the control. The decomposition rate of macrophytes in the semiarid condition of the landfill was slow, but, once composted, plant biomass was more applicable to soil. This macrophyte compost can then also be used as an economical substitute for the commercial barks currently used as co-composting material. Therefore, the composting of remediation macrophytes from the leachate channel of a sanitary landfill for application to soil will help in the sustainable management of both the leachate channels and the soils on the slopes.
\end{abstract}

Keywords: Composting, Leachate channel, Macrophyte, Plant response, Soil condition

\section{Introduction}

Modern civilization suffers from increasing concentrations of elemental pollutants in the environment because of industrialization, agricultural practices, and waste production [1-3], and this type of environmental contamination poses one of the largest threats because of toxicity to all organisms. Therefore, methods such as remediation and purification that can alleviate environmental pollution are essential for environmental management [4, 5]. Also reuse of wastewater and excreta became a global interest due to the associated risks to public health and the environment [2]. Phytoremediation is an emerging green technology that uses plants to remediate soil, water, and groundwater environments contaminated with toxic materials [6]. With this technology, the removal of hazardous compounds is effective, nonintrusive, inexpensive, and environmentally friendly [7]. Moreover, research on phytoremediation has expanded to investigate not only traditional remediation methods but also to include even the genetic engineering of plants [1] and microbiota interactions [8]. The study site for this investigation was the Sudokwon Landfill, Korea, which has

This is an Open Access article distributed under the term of the Creative Commons Attribution Non-Commercial License (http://creativecommons.org/licenses/by-nc/3.0/) which permits unrestricted non-commercial use, distribution, and reproduction in any medium, provided the original work is properly cited.

Copyright (C) 2020 Korean Society of Environmental Engineers over $5 \mathrm{~km}$ of leachate channel for remediation after chemical and physical treatment of leachate [9].

However, following plant uptake, the contaminants accumulated in vegetation are re-released during decomposition, which may limit the capacity for biodegradation [10]. Therefore, the suggestion of some studies is to use the biomass in an incineration plant as an energy source [11] or to make biofuel [12]. However, using contaminant-enriched biomass crops for the generation of energy remains difficult because of problems with efficiency and the toxic residues that remain after conversion [13]. The plants used for phytoremediation also contain useful components, such as organic matter, nitrogen, and phosphorus; however, research is limited on using these plants as potential fertilizers or composting materials [14]. Thus, research is required to provide a scientific basis to overcome this limitation.

In this study, pilot-scale research was conducted to test the feasibility of using the remediation macrophytes Phragmites australis and Typha angustifolia as composting materials. Composting and application and the responses of plants to compost were investigated.
Received February 24, 2019 Accepted August 31, 2019

${ }^{\dagger}$ Corresponding author

Email: uhrami@gmail.com

Tel: +82-64-754-3525

ORCID: 0000-0001-9182-0159 


\section{Materials and Methods}

\subsection{Study Site}

The Sudokwon Landfill is located in Incheon, Korea, and is one of the largest sanitary landfills in the world, with a gross area of approximately $20,000,000 \mathrm{~m}^{2}$. The landfill produces 6,700 tons of leachate per day [9] and is one of the largest leachate processing facilities in the world. The landfill has more than $5 \mathrm{~km}$ of leachate channel with a buffering wetland at the end that minimizes the effects of the leachate on the sea after release [15]. The geographic coordinates of the center of the landfill are $37^{\circ} 34^{\prime} 52^{\prime \prime} \mathrm{N}$ and $126^{\circ} 37^{\prime \prime}$ $29 " \mathrm{E}$. The average annual temperature and precipitation in this area during the research years (2008 and 2009) were $12.6^{\circ} \mathrm{C}$ and $1,255 \mathrm{~mm}$, respectively [16].

\subsection{Harvesting and Composting}

In July 2008, Phragmites australis and Typha angustifolia were harvested from the leachate channel of Sudokwon Landfill, Korea. These two species were the most abundant in the channel [15]. Manual labor was used for the harvesting because it was difficult to use machines in the submerged area. Harvested plants were chopped and dried for a few weeks and then used as co-composting material.

A pilot-scale windrow composting method was used for composting as pilot scale composting are often attempted in other related researches [17]. Composting was performed using effective microorganisms (EM) following instructions in the manual of composting [18]. Twenty kilograms of $P$. australis and $20 \mathrm{~kg}$ of $T$. angustifolia were mixed with $20 \mathrm{~kg}$ of sewage sludge, $20 \mathrm{~kg}$ of water, $10 \mathrm{~kg}$ of EM solution, and $0.5 \mathrm{~kg}$ of sugar, and the mixture was covered with several layers of thick vinyl tarp with several air holes. Compost was turned over every few days for an additional supply of air. The EM solution included Saccharomyces sp. $\left(4.3 \times 10^{2} \mathrm{cfu} / \mathrm{g}\right.$ of dry slurry), Rhodopseudomonas sp. (4.8 $\left.\times 10^{2} \mathrm{cfu} / \mathrm{g}\right)$, and Lactobacillus sp. $\left(1.9 \times 10^{7} \mathrm{cfu} / \mathrm{g}\right)$. The sewage sludge used in this research was from the same landfill, which produces 600 tons of sewage sludge daily [9]. Composting began on July 31, the hottest time of the year, and the temperature of compost during composting was measured with a HOBO H08 data logger (Onset Computer Corp., MA, USA). After the temperature of the compost stabilized, it was covered with several layers of tarps without holes until the following year.

\subsection{Compost Application and Plant Responses}

In the following spring, compost was applied to soil in a pot experiment. One herbaceous species (Brassica napus L.) and one woody species (Quercus acutissima) were tested for the effects of compost application in the experiment. Sawtooth oak $(Q$. acutissi$\mathrm{ma}$ ) was planted in pots (upper diameter of $19 \mathrm{~cm}$ and lower diameter of $16 \mathrm{~cm}$ ). Recently reclaimed soil from the landfill was collected and passed through a $2 \mathrm{~mm}$ sieve to remove gravel. In the compost treatment, a mixture of $25 \%$ sewage sludge compost and $75 \%$ (by volume) reclaimed soil was used; this percentage was based on previous research $[19,20]$ that determined the optimum sewage sludge compost application rate for plants. For Q. acutissima, in- dividuals with a shoot length between 35 and $40 \mathrm{~cm}$ were selected for the experiment. For B. napus, several seeds were planted in each pot, and, after 3 weeks, two seedlings were selected for the experiment, with the other seedlings removed. At harvest, one individual was randomly selected for measurement of biomass, but both individuals were used for the ICP analysis because the biomass of an individual control plant was too small. A total of ten replicates with plants were used for the experiment.

\subsection{Soil and Plant Analyses}

The soil was dried at $105^{\circ} \mathrm{C}$ for $48 \mathrm{~h}$ to measure the water content. The OM content was determined by loss on ignition (combustion at $550^{\circ} \mathrm{C}$ for $4 \mathrm{~h}$ ) [21]. Sample $\mathrm{C}$ and $\mathrm{N}$ contents were determined with an elemental analyzer (Flash EA 1112; Thermo Electron Co.).

For heavy metal analysis, $1 \mathrm{~g}$ of dried and milled soil, compost, or plant (for analysis of Brassica napus from the control, $0.1 \mathrm{~g}$ of plant was used) was pretreated with $60 \% \mathrm{HNO}_{3}$ for $24 \mathrm{~h}$ and then heated to $80^{\circ} \mathrm{C}$ for $2 \mathrm{~h}$. Ten milliliters of $70 \%$ perchloric acid was added, and the solution was heated to $200^{\circ} \mathrm{C}$ until it became clear. The samples were filtered with Whatman 44 filter paper, and the elemental contents were analyzed using an ICP emission spectrometer (ICPS-1000IV; Shimadzu, Japan).

\subsection{Plant Ecophysiological Analyses}

Total antioxidant enzyme activities of the plants were measured using the protocols of Song and Lee, 2010b. Superoxide dismutase (SOD) activity was measured using the method of Peskin and Winterbourn [22] and the manufacturer's recommended protocol for preparing the water-soluble tetrazolium salt used in the SOD assay (Dojindo, Japan). Chlorophyll contents of the plants were measured using the DMSO extraction method [23]. All physiological parameters were measured in August, and plants were harvested for other analyses in October.

\subsection{Statistical Analyses}

A one-way ANOVA was performed to identify significant differences among treatments, and, when detected, a post hoc Duncan's Multiple Range Test was performed using the SAS 9.1 statistical software package (SAS Institute Inc., USA). Differences between two groups or treatments were analyzed using a t-test (SAS 9.1). The differences were considered significant when $\mathrm{p}<0.05$

\section{Results and Discussion}

Harvesting and composting were conducted in the summer, because the temperatures were the highest of the year. In previous research conducted in 2006, heat loss was a major concern during the composting process [15]; therefore, the composting began on July 31, the hottest time of the year. For plants harvested after the growing season at approximately the beginning of November, the temperature soon begins to drop below $0^{\circ} \mathrm{C}$, and composting is affected by the low temperatures [15]. Therefore, by composting in summer, the loss of heat was minimized. Additionally, the macrophyte species reached maximum biomass in the summer [24] and not in 
Table 1. Chemical Characteristics of Sewage Sludge, Compost, and Reclaimed Soil Before and After Addition of Compost

\begin{tabular}{lrrrr}
\hline & Sludge & Reclaimed soil & Compost & Soil after compost treatment \\
$\mathrm{C}(\%)$ & $25.1 \pm 0.9^{\mathrm{a}}$ & $1.2 \pm 0.2^{\mathrm{c}}$ & $28.7 \pm 1.1^{\mathrm{a}}$ & $5.7 \pm 2.1^{\mathrm{b}}$ \\
$\mathrm{N}(\%)$ & $3.8 \pm 0.1^{\mathrm{a}}$ & $0.1 \pm 0.0^{\mathrm{d}}$ & $2.7 \pm 0.2^{\mathrm{b}}$ & $0.6 \pm 0.0^{\mathrm{c}}$ \\
$\mathrm{Pb} \mathrm{(mg/kg)}$ & $179.9 \pm 3.6^{\mathrm{a}}$ & $25.21 \pm 1.4^{\mathrm{c}}$ & $102.8 \pm 7.9^{\mathrm{b}}$ & $38.2 \pm 1.8^{\mathrm{C}}$ \\
$\mathrm{Cd}(\mathrm{mg} / \mathrm{kg})$ & $1.8 \pm 0.0^{\mathrm{a}}$ & $0.2 \pm 0.1^{\mathrm{c}}$ & $0.7 \pm 0.1^{\mathrm{b}}$ & $0.4 \pm 0.2^{\mathrm{bc}}$ \\
$\mathrm{Cr}(\mathrm{mg} / \mathrm{kg})$ & $2.6 \pm 0.1^{\mathrm{a}}$ & $0.1 \pm 0.0^{\mathrm{c}}$ & $1.5 \pm 0.1^{\mathrm{b}}$ & $0.2 \pm 0.0^{\mathrm{c}}$ \\
$\mathrm{Cu}(\mathrm{mg} / \mathrm{kg})$ & $64.6 \pm 1.9^{\mathrm{a}}$ & $10.1 \pm 1.4^{\mathrm{c}}$ & $29.8 \pm 2.8^{\mathrm{b}}$ & $11.4 \pm 1.8^{\mathrm{c}}$
\end{tabular}

Data are presented as the mean of three replicates (mean $\pm \mathrm{SE}$ ).

Means within a row followed by the same letter are not significantly different at the level of 0.05 (Duncan's Multiple Range Test). Soil was analyzed $5 \mathrm{~m}$ after compost application.

Table 2. Chlorophyll Contents of Brassica napus and Quercus acutissima by Treatment

\begin{tabular}{lcccccccc}
\hline Plant & \multicolumn{3}{c}{ Brassica napus } & & \multicolumn{3}{c}{ Quercus acutissima } \\
\hline Chlorophyll & Chl a & Chl b & Total & & Chl a & Chl b & Total \\
\hline Compost & $15.7 \pm 0.3$ & $6.0 \pm 0.2$ & $21.2 \pm 0.2$ & & $19.0 \pm 0.6$ & $8.3 \pm 0.3$ & $27.3 \pm 0.9$ \\
Reclaimed soil & $12.7 \pm 0.2$ & $4.3 \pm 0.2$ & $16.9 \pm 0.3$ & & $15.8 \pm 0.5$ & $7.1 \pm 0.3$ & $22.8 \pm 0.5$ \\
\hline$P$-value & $<0.001$ & $<0.001$ & $<0.001$ & & $<0.001$ & $<0.001$ & $<0.001$ \\
\hline
\end{tabular}

Data are presented as the mean \pm SE of five replicates.

${ }^{*}$ Only p-values $<0.05$ (significantly different) are shown (t-test).

the fall; thus summer harvest increased harvestable biomass.

Fig. 1 shows compost temperature during the composting process. The temperature was elevated over $50^{\circ} \mathrm{C}$, indicating that the compost was well-processed [25]. The windrow composting required no special equipment and only space and covering materials; therefore, windrow composting would be a very effective and cost-saving method [26]. Additionally, the investment for windrow composting facilities is low, the environmental-friendliness is high, the operation is easy, and the failure rate is low [27]. Because most macrophytes are not suitable for large-scale harvesting (difficult to use machines in submerged area), and windrow composting may be more optimal for local and small-scale remediation wetlands. Moreover, with 2-6 months required for traditional windrow composting to mature [28], summer composting would produce compost suitable for application in the following spring.

Table 1 shows the chemical characteristics of sewage sludge, compost, and reclaimed soil. Nitrogen content of sewage sludge was reduced after composting, but the contents of heavy metals were also reduced. As a co-composting material, macrophytes act as a diluent for heavy metal enriched sewage sludge; thus macrophyte composting had the benefit of reducing the concentrations of heavy metals in sludge [29]. The $\mathrm{N}$ and $\mathrm{C}$ contents of reclaimed soil were very low, but compost application increased the contents (Table 1), and, with a 6-fold increase in $\mathrm{N}$ content of the soil, the compost was an effective fertilizer. Of the heavy metals, only the Cd content of soil increased significantly with compost application, but the Cd concentrations were much lower than those of the Ecological Soil Screening Level for plants (32 mg/kg) set by the United States Environmental Protection Agency [30]. Other values were also lower than those of the Ecological Soil Screening Level for birds: $\mathrm{Pb}, 120$; $\mathrm{Cu}, 70$, and $\mathrm{Cr}, 26$ [31]. Therefore, the application of macrophyte compost was safe.

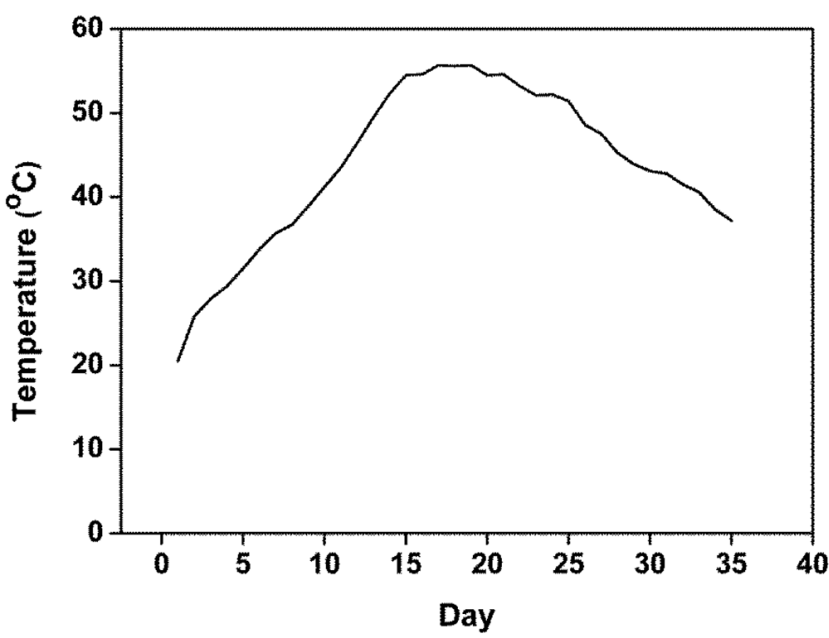

Fig. 1. Changes in core temperature of compost during composting process.

Quercus acutissima was selected for the compost application experiment because the species is planted in the landfill for landscape management [19]. The herbaceous plant B. napus was selected because the plant showed good potential for seed-spray restoration of the landfill slopes [32]; additionally, an herbaceous plant was not tested with compost application in previous research [19, 20]. In the compost treatment, the chlorophyll contents increased significantly in both species (Table 2). Because the nutrient content of reclaimed soil was poor (Table 1), the plant suffered from nutrient deficiency and low levels of physiological activities. The plants were irrigated regularly, and therefore did not suffer water stress; however, in the field, because of the low $\mathrm{C}$ content of reclaimed 


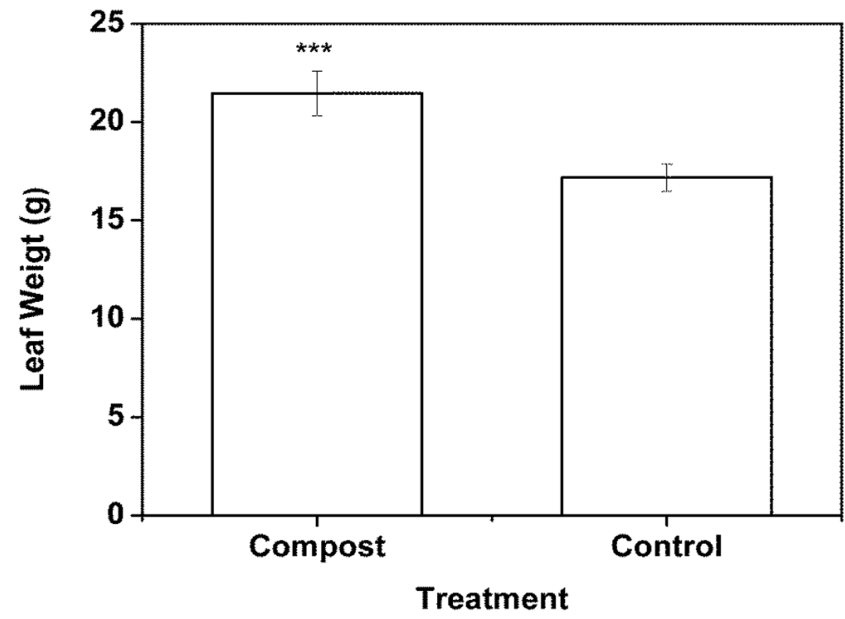

Fig. 2. Biomass of Quercus acutissima leaves (fresh weight) by treatment. Bars and error bars represent the mean \pm SE of ten replicates. $*_{\mathrm{p}}<0.05 ; * * \mathrm{p}<0.01 ; * * \mathrm{p}<0.001$ (t-test).

soil, the organic matter content and water holding capacity of soils were low, and plants likely suffered from moisture deficits. Plant biomass was clearly different between control and compost treatments, and, in the compost treatment, the biomass of leaves of Q. acutissima was significantly greater than that of control plants (Fig. 2). Although the original plan was to measure the growth of $Q$. acutissima by the change in height, the growth of $Q$. acutissima was not by the primary stem and many branches formed instead; therefore, the biomass of leaves was measured. The leaf biomass of $Q$. acutissima increased by approximately $30 \%$ in the compost treatment. For the herb B. napus, the biomass was dramatically different (Fig. 3), with the biomass of compost treatments more than 10 -fold that of $B$. napus in the control. Because B. napus germinates from seeds, these plants do not have any energy stores, such as in the roots of trees, and therefore the plant biomass of $B$. napus in the control soil reflected the lack of nutrients [33]. As mentioned previously, these herbaceous plants have high potential for seed spraying on landfill slopes immediately after reclamation, and, with macrophyte compost, plant growth could improve in the poor conditions of reclaimed soil.

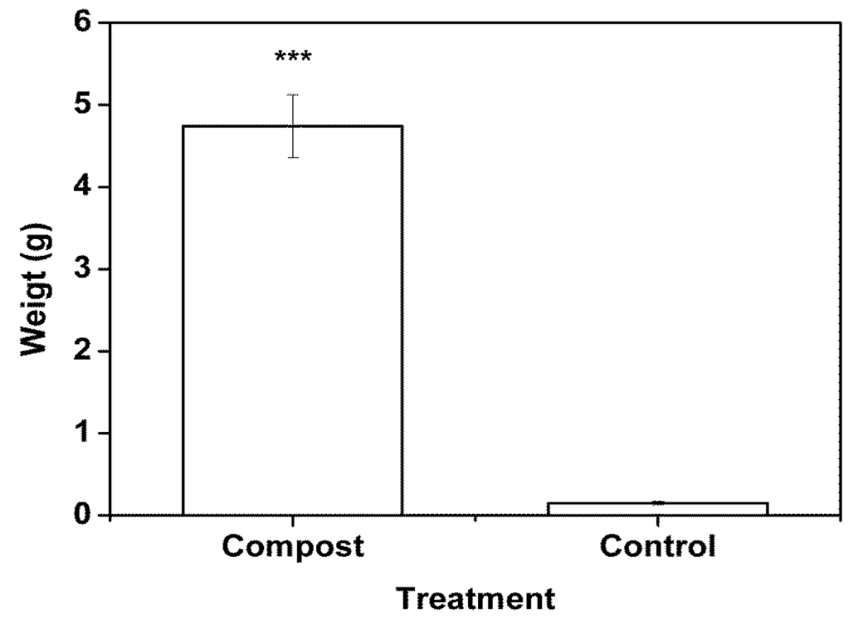

Fig. 3. Aboveground biomass of Brassica napus (fresh weight) by treatment. Bars and error bars represent the mean \pm SE of ten replicates. ${ }^{*} p<0.05 ;{ }^{* *} p<0.01 ;{ }^{* * *} p<0.001$ (t-test)

The greatest concern with the application of sewage sludge compost is the contamination of soil and subsequent bioaccumulation of potential toxic materials in plants [34]. In the analysis of bioaccumulation, $\mathrm{Cu}$ was not measured because the concentrations in control soil and soil with compost addition were not different (Table 1). Therefore, Fe and $\mathrm{Zn}$ were analyzed, because Fe is the most abundant material in landfill leachate [7] and $\mathrm{Zn}$ is often deficient in the soil and plants of a reclaimed area. For Q. acutissima, no significant differences were observed between control and compost treatments (Table 3), which indicated that bioaccumulation was not very high [35]. However, for $B$. napus, the results for bioaccumulation were notable, and, except for $\mathrm{Zn}$, Fe and $\mathrm{Pb}$ concentrations were significantly higher in the control than in compost-treated soil. Because reclaimed soil (control) also had a certain content of heavy metals and the concentration did not change significantly in soil after compost application, the heavy metal contents were expected to be similar. However, the concentrations of $\mathrm{Fe}$ and $\mathrm{Pb}$ for control treatment were much higher, approximately 4-fold for $\mathrm{Fe}$ and 6-fold for $\mathrm{Pb}$. Because the growth of B. napus in the control soil was very limited (Fig. 3), the high heavy metal

Table 3. Element Contents of Brassica Napus and Quercus Acutissima by Treatment

\begin{tabular}{|c|c|c|c|c|}
\hline & \multicolumn{2}{|c|}{ Brassica napus } & \multicolumn{2}{|c|}{ Quercus acutissima } \\
\hline & Reclaimed soil & Compost & Reclaimed soil & Compost \\
\hline C (\%) & $39.15 \pm 0.10$ & $39.80 \pm 0.01$ & $47.92 \pm 0.08$ & $47.87 \pm 0.18$ \\
\hline N (\%) & $0.99 \pm 0.04$ & $1.13 \pm 0.01^{* * *}$ & $1.85 \pm 0.04$ & $1.98 \pm 0.04$ \\
\hline $\mathrm{Cd}(\mathrm{mg} / \mathrm{kg})$ & $0.23 \pm 0.01$ & $0.26 \pm 0.01$ & $0.22 \pm 0.01$ & $0.25 \pm 0.02$ \\
\hline Cr (mg/kg) & $1.84 \pm 0.09$ & $2.07 \pm 0.06$ & $1.72 \pm 0.04$ & $1.69 \pm 0.06$ \\
\hline $\mathrm{Fe}(\mathrm{mg} / \mathrm{kg})$ & $133.2 \pm 3.9^{* * *}$ & $35.6 \pm 2.6$ & $133.6 \pm 11.4$ & $104.9 \pm 6.8$ \\
\hline $\mathrm{Pb}(\mathrm{mg} / \mathrm{kg})$ & $5.21 \pm 0.34^{* \star *}$ & $0.89 \pm 0.21$ & $154.9 \pm 44.4$ & $524.8 \pm 130.3$ \\
\hline $\mathrm{Zn}(\mathrm{mg} / \mathrm{kg})$ & $21.58 \pm 0.92$ & $76.31 \pm 3.70^{* * *}$ & $24.10 \pm 0.76$ & $27.14 \pm 5.01$ \\
\hline
\end{tabular}

Data are presented as the mean \pm SE of three replicates.

${ }^{*} \mathrm{p}<0.05 ;{ }^{* *} \mathrm{p}<0.01 ;{ }^{* * *} \mathrm{p}<0.001$ (t-test). 
Table 4. Antioxidant Enzyme Activities of Plants After Compost Treatment

\begin{tabular}{lccccc}
\hline Plant & \multicolumn{2}{c}{ Brassica napus } & \multicolumn{2}{c}{ Quercus acutissima } \\
\hline Items & TAC & SOD & TAC & SOD \\
\hline Reclaimed soil & $1.101 \pm 0.029$ & $0.087 \pm 0.002$ & $0.568 \pm 0.046$ & $1.137 \pm 0.159$ \\
Compost & $1.045 \pm 0.039$ & $0.125 \pm 0.005$ & $0.455 \pm 0.039$ & $0.683 \pm 0.183$ \\
P-value & & $<0.001$ & 0.036 & $<0.001$ \\
\hline
\end{tabular}

Data are presented as the mean \pm SE of five replicates.

*Only p-values $<0.05$ (significantly different) are shown (t-test).

contents might be explained by a dilution effect [36]. The plants in compost grew much faster than those in the control, and, although the total content of heavy metals absorbed was higher in compost-treated soil, the per weight concentrations were diluted compared with those of the control. For $\mathrm{N}$, the content of $B$. napus increased significantly in compost-treated soil, which demonstrated that the macrophyte compost increased soil nutrient availability.

As shown in Table 4, antioxidant activities did not increase in the compost treatment, except for SOD of canola, and other measurements showed higher values in reclaimed soil. Sewage sludge compost contains heavy metals and other toxic materials, as previously discussed, thereby increasing the stress of plants. However, the results indicated that the plants were under greater stress because of poor soil conditions. With the status of the soil poor (Table 1), plant growth would be difficult and the level of stress high. Therefore, compost application should be effective in reducing plant stress. However, in this study, the measurements were conducted a few months after compost application and therefore did not measure the initial stress immediately after application when it was likely higher. After a few months, the beneficial effects of compost likely became apparent and reduced the stress of plants in poor soil. The compost would also help rooting of plants on reclaimed soil. Therefore, sewage sludge compost made with macrophytes from leachate channels can be used effectively, and the use has multiple merits that include fertilizing and preventing decomposition in the leachate channel.

The reasons why macrophytes should be composted before application to landfill soil are based on litterbag research of the author and other related plant decomposition research supports requirement of composting [35]. As mentioned in the Introduction, the plants used for phytoremediation will eventually decompose in the leachate channel (or in the remediation wetlands) and re-release accumulated toxic materials. Thus, these plants must be harvested, but the harvested biomass is difficult to recycle. The direct application (spraying chips on soil) of litter on soil without composting was easily accomplished, but, as shown in Fig. 4, the decomposition rates were very slow. With slow decomposition, the litter of macrophytes can be easily washed away by rainfall, and therefore composting is required before application [12].

The decomposition rates of $T$. angustifolia were faster than those of $P$. australis, likely because $P$. australis had very recalcitrant stems. In harvested litterbags, the stems of $P$. australis showed little change, whereas the leaves decayed rapidly. Moreover, even for $T$. angustifolia, the decomposition rates were much slower than those obtained in previous research [37], likely because the landfill was very dry (almost semiarid) in some areas [32]. Because the

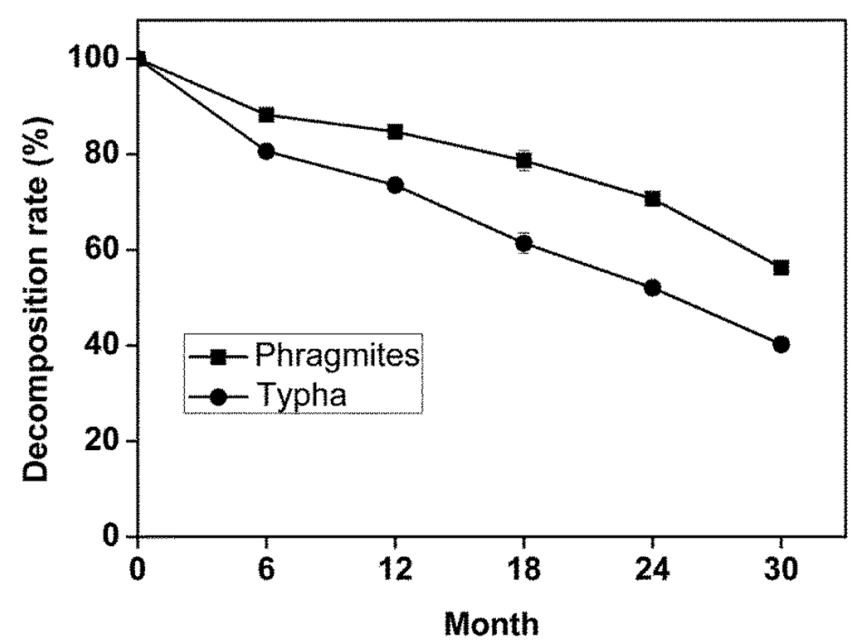

Fig. 4. Decomposition rates of Phragmites australis and Typha angustifolia in litterbags on a landfill slope. Symbols and bars represent the mean \pm SE of three replicates.

decomposition rates of $T$. angustifolia were faster than those of $P$. australis, $T$. angustifolia would be better for application to landfill slopes; however, $P$. australis would also eventually decompose, and therefore both species can be used for application. The barks typically used as co-composting material are expensive [19], and therefore the use of macrophytes also provides an economical method to prepare a soil conditioner for the reclaimed soil of landfills.

\section{Conclusions}

The plants used for phytoremediation in the leachate channel of a sanitary landfill must be harvested and recycled after the uptake contaminants to avoid their re-release during decomposition. The composting of the remediation macrophytes Phragmites australis and Typha angustifolia solved this problem. Additionally, the composted macrophytes significantly improved soil conditions compared with the very poor reclaimed soil. Plants grown with macrophyte compost applied to soil increased performance as measured by chlorophyll content, a stress evaluation, and increase in biomass. The accumulation of toxic materials in plants was not high, and the accumulation of some elements was even lower with compost added to soil. Because the decomposition rate of macrophyte litter in the semiarid conditions of the landfill was slow, composting converted plant biomass to a form more applicable to soil that 
could also be an economical substitute for the commercial barks currently used for co-composting material. Harvesting and composting remediation plants will help to manage leachate channels and also improve soil conditions on huge landfill sites that require soil conditioning. Therefore, using the macrophytes from the leachate channel of a sanitary landfill for composting and soil application can help in the sustainable management of the leachate channels and the soils on the slopes of the landfill.

\section{Acknowledgments}

This research was supported by the 2018 scientific promotion program funded by Jeju National University.

\section{Author Contributions}

U.R.S. (Ph.D.) designed and conducted all the experiments and wrote the manuscript.

\section{References}

1. Eapen S, D'Souza SF. Prospects of genetic engineering of plants for phytoremediation of toxic metals. Biotechnol. Adv. 2005;23:97-114.

2. Aljerf L. High-efficiency extraction of bromocresol purple dye and heavy metals as chromium from industrial effluent by adsorption onto a modified surface of zeolite: Kinetics and equilibrium study. J. Environ. Manage. 2018;225:120-132.

3. Jaramillo MF, Restrepo I. Wastewater reuse in agriculture: A Review about Its Limitations and Benefits. Sustainability 2017;9:1734.

4. Guerra F, Attia M, Whitehead D, Alexis F. Nanotechnology for environmental remediation: Materials and applications. Molecules 2018;23:1760.

5. Aljerf L. Advanced highly polluted rainwater treatment process. J. Urban Environ. Eng. 2018;12:50-58.

6. Paz-Alberto AM, Sigua GC. Phytoremediation: A green technology to remove environmental pollutants. Am. J. Clim. Change 2013;2:71-86.

7. Alkorta I, Hernández-Allica J, Becerril JM, et al. Recent findings on the phytoremediation of soils contaminated with environmentally toxic heavy metals and metalloids duch as zinc, cadmium, lead, and arsenic. Rev. Environ. Sci. Biotechnol. 2004;3:71-90.

8. Titah HS, Abdullah SRS, Mushrifah I, et al. Effect of applying rhizobacteria and fertilizer on the growth of Ludwigia octovalvis for arsenic uptake and accumulation in phytoremediation. Eco. Eng. 2013;5:303-313.

9. Sudokwon landfill site management corporation (SLMC). Facilities of Sudokwon Landfill Site Management Corporation with paintings [Internet]. c2013 [cited 23 January 2013]; Available from: http://englishslcorkr/business/leachate/facilitiesasp.

10. Helfield JM, Diamond ML. Use of constructed wetlands for urban stream restoration: A critical Analysis. Environ. Manage.
1997;21:329-341.

11. Brooks RR, Chambers MF, Nicks LJ, Robinson BH. Phytomining. Trends Plant Sci. 1998;3:359-62.

12. Song U. Post-remediation use of macrophytes as composting materials for sustainable management of a sanitary landfill. Int. J. Phytoremediat. 2017;19:395-401.

13. Witters N, Mendelsohn RO, Van Slycken S, et al. Phytoremediation, a sustainable remediation technology? Conclusions from a case study. I: Energy production and carbon dioxide abatement. Biomass Bioenerg. 2012;39:454-69.

14. Sundaralingam T, Gnanavelrajah N. Phytoremediation potential of selected plants for nitrate and phosphorus from ground water. Int. J. Phytoremediat. 2014;16:275-284.

15. Song U. Ecological Monitoring and Management of Plant, Soil and Leachate Channel in the Sudokwon Landfill, Korea [dissertation]. Seoul: Seoul National Univ; 2010.

16. Korean Meteorological Administration (KMA). Observed weather data of past [Internet]. c2010 [cited 4 April 2010]. Available from: http://www.kma.go.kr/weather/observation/past_tablejsp? $\operatorname{stn}=112 \& y y=2009 \& o b s=07 \& x=25 \& y=11$.

17. Singh WR, Das A, Kalamdhad A. Composting of water hyacinth using a pilot scale rotary drum composter. Environ. Eng. Res. 2012;17:69-75.

18. EM-center. Teaching material of environmental agriculture. Effective microorganisms Center of Korea: Jeju Island, Korea; 2003.

19. Song U, Lee EJ. Environmental and economical assessment of sewage sludge compost application on soil and plants in a landfill. Resour. Conserv. Recy. 2010;54:1109-1116.

20. Song U, Lee E. Ecophysiological responses of plants after sewage sludge compost applications. J. Plant Biol. 2010;53:259-267.

21. Hoogsteen MJJ, Lantinga EA, Bakker EJ, Tittonell PA. An Evaluation of the loss-on-ignition method for determining the soil organic matter content of calcareous soils. Commun. Soil Sci. Pl Al. 2018;49:1541-1552.

22. Peskin AV, Winterbourn CC. A microtiter plate assay for superoxide dismutase using a water-soluble tetrazolium salt (WST-1). Clin. Chim. Acta. 2000;293:157-166.

23. Hiscox JD, Israelstam GF. A method for the extraction of chlorophyll from leaf tissue without maceration. Can J. Bot. 1979;57:1332-1334

24. Engloner AI. Structure, growth dynamics and biomass of reed (Phragmites australis) - A review. Flora 2009;204:331-346.

25. Epstein E. The science of composting. Chicago; Technomic Publishing Company; 1997. p. 37.

26. Chen Y-T. A cost analysis of food waste composting in Taiwan. Sustainability 2016;8:1210.

27. Tai H-S, He W-H. A novel composting process for plant wastes in Taiwan military barracks. Resour. Conserv. Recy. 2007;51: 408-417.

28. Wei YS, Fan YB, Wang MJ, Wang JS. Composting and compost application in China. Resour. Conserv. Recy. 2000;30:277-300.

29. Kouki S, Saidi N, M'hiri F, Amor H, Hassen A. Co-composting of macrophyte biomass and sludge as an alternative for sustainable management of constructed wetland by-products. CLEAN - Soil, Air, Water 2016;4:694-702.

30. United States Environmental Protection Agency U. Ecological soil screening levels for Cadmium: Wallingford Oxon: CABI 
Publishing; 2005.

31. United States Environmental Protection Agency U. Ecological soil screening levels: CABI Publishing. Wallingford Oxon, U.K.; 2015.

32. Song U, Waldman B, Lee E. Ameliorating topsoil conditions by biosolid application for a waste landfill landscape. Int. J. Environ. Res. 2013;7:1-10.

33. Meng H, Hua S, Shamsi IH, Jilani G, Li Y, Jiang L. Cadmium-induced stress on the seed germination and seedling growth of Brassica napus L., and its alleviation through exogenous plant growth regulators. Plant Growth Regul. 2009;58:47-59.

34. Singh RP, Agrawal M. Potential benefits and risks of land appli- cation of sewage sludge. Waste Manage. 2008;28:347-358.

35. Civeira G. Influence of municipal solid waste compost on soil properties and plant reestablishment in peri-urban environments. Chil. J. Agric. Res. 2010;7:446-453.

36. Korboulewsky N, Bonin G, Massiani C. Biological and ecophysiological reactions of white wall rocket (Diplotaxis erucoides L.) grown on sewage sludge compost. Environ. Pollut. 2002;117: 365-370.

37. Kominkova D, Kuehn K, Büsing N, Steiner D, Gessner M. Microbial biomass, growth, and respiration associated with submerged litter of Phragmites australis decomposing in a littoral reed stand of a large lake. 2000;22:271-282. 